572 Resumos das teses e dissertações apresentadas no PPG/UnB

\title{
As regras da metrópole: campo urbanístico e ordem social na Região Metropolitana de São Paulo
}

Jeová Dias Martins

Curso: Doutorado em Sociologia

Data de defesa: 13 de junho de 2006

Orientador: Prof. Dr. Brasilmar Ferreira Nunes 


\section{Resumo}

O estudo analisa o aparecimento e estruturação de um agrupamento social que reivindica o controle do processo de produção do espaço, com ênfase na dimensão institucional-cognitiva, tendo como base empírica a Região Metropolitana de São Paulo. O principal objetivo é contribuir para a explicação da conduta dessa comunidade humana, bem como avaliar a amplitude e profundidade da influência e condicionamento que ela exerce sobre o dever-ser da metrópole e da ordem social. Desse ponto de vista, são postos em relevo os agentes e instituições produtores de esquemas de percepção e apreciação que dão origem a modelos sociocognitivos de metrópole, princípios geradores de práticas sociais de produção, apropriação e consumo do espaço urbano.

A tese central é que a produção do espaço e da ordem social na metrópole não resulta da cooperação espontânea de indivíduos isolados nem do funcionamento do livre mercado como instituição auto-regulável, mas da competição e cooperação de agentes e instituições especializadas no interior de um espaço social específico, a saber, o campo urbanístico. Argumenta que, como espaço social hierarquizado de agentes e instituições que estabelecem relações objetivas, o campo urbanístico desenvolve autonomia relativa, isto é, cria suas próprias regras de funcionamento e de reprodução, em relação a outros espaços sociais (jurídico, político, científico) e à sociedade em geral. Explicita a dinâmica de constituição de modelos de realidade urbana, e como eles são transpostos para o território como uma coleção de objetos interconectados e comunicantes que dão coerência e sentido à dominação organizada da metrópole.

Conclui que a atividade social de produção do espaço na Região Metropolitana de São Paulo é, de modo crescente, influenciada e condicionada (embora não determinada) pelo que ocorre no campo 
urbanístico e suas interações com outros campos de produção material e simbólica. O espaço produzido é resultado de uma luta política e cognitiva que vai do local ao global, conformando uma nova divisão do trabalho de dominação organizada onde "cidademercado" e o "direito à cidade" surgem como modelos de realidade urbana em disputa pelo monopólio da definição legítima do deverser da metrópole.

Palavras-chave: sociologia urbana, urbanização, produção do espaço, ordem social, metrópole, Região Metropolitana de São Paulo, campo urbanístico. 